tion, which checked the spasm about the third inhalation. As I had my finger on the pulse all the while, I noticed that it disappeared with the spasm. I at once applied my ear to the chest and noticed that the heart was beating at about the rate of 250 per minute. This rate lasted perhaps. twenty seconds, then dropped to the rate of about twenty-five beats to the minute. This pulse-rate continued about ten seconds, when the heart stopped. Respiration was not perceptible after the spasm left.

I learned from the attending physician a history of malaria. Patient had been treated with domestic remedies for "dumb chill" for two weeks previous to the attack, the last chill leaving patient with vomiting and fever, for which the physician was called in about four hours previous to the convulsion. He did not consider patient seriously sick, and was shocked to learn of the sudden termination of the case.

W. F. ROCHELIE, M.D.

Jackson, Tenn., December 8, 1890 .

\section{Seventh International Congress of Hygiene and Demograghy.}

To the Editor:-I am requested by the Honorary Secretaries of the Committee of Organization of the Seventh International Congress of Hygiene and Demography, to call attention to the fact that this Congress will be held in London during the week beginning August Io, I 89 I.

The Governments of all countries, and municipalities, and all public health authorities, universities, colleges and societies occupied in the study of the sciences more or less immediately connected with hygiene, are invited to coöperate and appoint delegates to represent them at the Congress. The Prince of Wales will preside.

A Committee of Organization has been formed of which Sir Douglas Galton is Chairman, and Prof. W. H. Corfield and Mr. Shirley F. Murphy are Honorary Secretaries. An exhibition of articles of hygienic interest will be held in connection with the Congress. The last of these Congresses was held in Vienna in I887, and was attended by over 2,000 persons, and it is expected that the London meeting will be one of great magnitude and importance. Very respectfully, JoEN S. BILIINGS, M.D., Member of the International Permanent Committee.

Washington, D. C., October 27, 1890.

Dr. Samuel Bourne SwetT, the Boston Surgeon, died December 6 . He was probably the last survivor of that colony of young physicians in Paris of whom Holmes has lately written in the Atlantic Monthly. He graduated from the Jefferson Medical College in $\mathbf{1 8 3 4}$.

\section{NEW INSTRUMENTS.}

\section{KOCH'S HYPODERMIC SYRINGE.}

A very important result of bacteriological study is seen in the introduction of instruments that can be readily and thoroughly sterilized. To 8 this end surgical instruments are now made as simple as possible and with the fewest number of crevices for the accumulation of dirt. An instrument, to be acceptable at this day, must possess not only simplicity of form but must also contain no materials that prevent it from being subjected to the most approved methods of sterilization.

In order to secure the advantages of an entirely aseptic instrument for the injection of his inoculation $1 \mathrm{ymph}$, Prof. Koch has invented a new syringe to take the place of the old Pravaz pattern. Owing to the universality of the interest taken in Koch's new method of treating tuberculosis, this instrument will doubtless come rapidly into vogue throughout the world.

Through the courtesy of Messrs. Chas. Truax $\&$ Co., of Chicago, we are enabled to present a cut of one of the first of these instruments to be imported into this country, It is a very simple matter to sterilize this syringe each time after use. To accomplish this purpose a rubber bulb has been substituted for the piston of the older instruments. The cylinder is provided with a centimetre scale etched upon the glass, each division of the scale representing one-tenth $\mathrm{ccm}$. The metal work of the syringe is particularly well fitted to the cylinder in an air-tight manner. So that the instrument can easily be taken apart and cleansed, which is best accomplished by means of absolute alcohol.

\section{NECROLOGY.}

Dr. James L. STEwar'T, died December 6, at his home in Erie, Pa., aged 66 years. He graduated from the Medical Department University of Pennsylvania in 1848 , and entered the U. S. service as surgeon of the 3 rd Pennsylvania Cavalry in July or August, I86r, but resigned March I I, 1862, after a hospital experience in Washington, D. C. He became President of the Penn- 